\title{
DEGUM-Wissenschaftspreis 2019
}

Während des 43. Dreiländertreffens in Leipzig wurde der DEGUM-Wissenschaftspreis 2019 verliehen. Dr. med. Katharina Linden von der Abteilung für Kinderkardiologie des Zentrums für Kinderheilkunde des Universitätsklinikums Bonn erhielt die Auszeichnung für die Arbeit „Left Atrial Volumes and Phasic Function in Healthy Children: Reference Values Using Real-Time Three-Dimensional Echocardiography“.

Unsere herzlichsten Glückwünsche an die Preisträgerin.

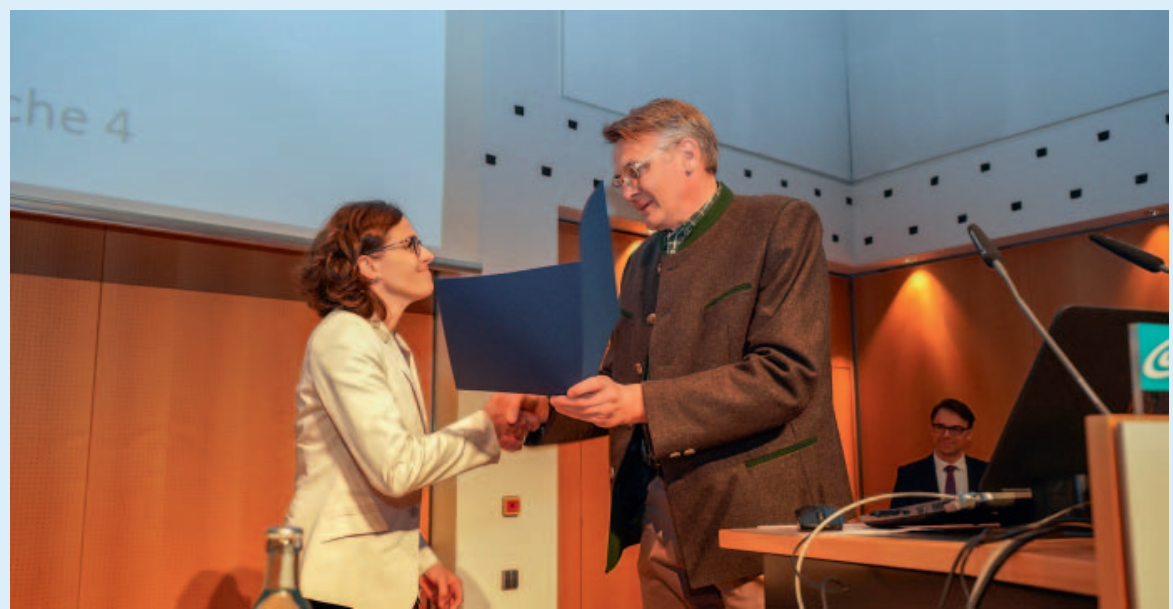

Wissenschaftspreisträgerin 2019 Dr. K. Linden (links) mit dem Präsidenten der DEGUM, Prof. P. Jecker (rechts). Foto: DEGUM. 